\title{
Review of Pacific Northwest
}

Laboratory Research on

Aquatic Effects of

Hydroelectric Generation and

Assessment of Research Needs

D. H. Fickeisen

C. D. Becker

D. A. Neitzel

May 1981

Prepared for the U.S. Department of Energy under Contract DE-AC06-76RLO 1830

Pacific Northwest Laboratory

Operated for the U.S. Department of Energy

by Battelle Memorial Institute 


\title{
NOTICE
}

This report was prepared as an account of work sponsored by the United States Government. Neither the United States nor the Department of Energy, nor any of their employees, nor any of their contractors, subcontractors, or their employees, makes any warranty, express or implied, or assumes any legal liability or responsibility for the accuracy, completeness or usefulness of any information, apparatus, product or process disclosed, or represents that its use would not infringe privately owned rights.

The views, opinions and conclusions contained in this report are those of the contractor and do not necessarily represent those of the United States Government or the United States Department of Energy.

\author{
PACIFIC NORTHWEST LABORATORY \\ operated by \\ BATTELLE \\ for the \\ UNITED STATES DEPARTMENT OF ENERGY \\ Under Contract DE-AC06-76RLO 1830
}

\author{
Printed in the United States of America \\ Available from \\ National Technical Information Service \\ United States Department of Commerce \\ 5285 Port Royal Road \\ Springfield, Virginia 22151
}

Price: Printed Copy \$

$\therefore$ Microfiche $\$ 3.00$

$\begin{array}{cc}\text { •Pages } & \begin{array}{c}\text { NTIS } \\ \text { Selling Price }\end{array} \\ 001-025 & \$ 4.00 \\ 026-050 & \$ 4.50 \\ 051-075 & \$ 5.25 \\ 076-100 & \$ 6.00 \\ 101-125 & \$ 6.50 \\ 126-150 & \$ 7.25 \\ 151-175 & \$ 8.00 \\ 176-200 & \$ 9.00 \\ 201-225 & \$ 9.25 \\ 226-250 & \$ 9.50 \\ 251-275 & \$ 10.75 \\ 276-300 & \$ 11.00\end{array}$


REVIEW OF PACIFIC NORTHWEST LABORATORY RESEARCH ON AQUATIC EFFECTS OF HYDROELECTRIC GENERATION AND ASSESSMENT OF RESEARCH NEEDS

D. H. Fickeisen

C. D. Becker

D. A. Neitzel

May 1981

Prepared for

the U.S. Department of Energy

under Contract DE-ACO6-76RLO 1830

Pacific Northwest Laboratory

Richland, WA 99352 
. 


\section{PREFACE}

This report is an overview of Pacific Northwest Laboratory's (PNL) research on how hydroelectric generation affects aquatic biota and environments. We describe the major accomplishments of our research and identify additional work needed to permit optimal use of available data. Our research goals are to: 1) identify impacts of hydroelectric generation, 2) provide guidance in allocating scarce water resources, and 3) develop techniques to avoid or reduce the impacts on aquatic communities or to compensate for unavoidable impacts.

Through our laboratory and field experments, we are developing an understanding of the generic impacts of hydrogeneration. Because PNL is located near the Columbia River, which is extensively developed for hydroelectric generation, we use it as a natural laboratory for studying a large-scale operating system. Although the impacts we study result from a particular system of dams and operating procedures and occur within a specific ecosystem, the results of our studies also have application at hydroelectric generating facilities throughout the United States. 



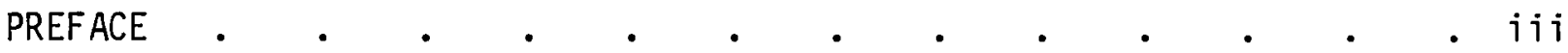

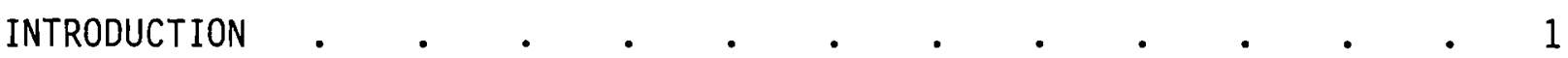

EFFECTS OF HYDROGENERATION

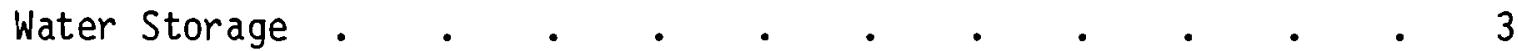

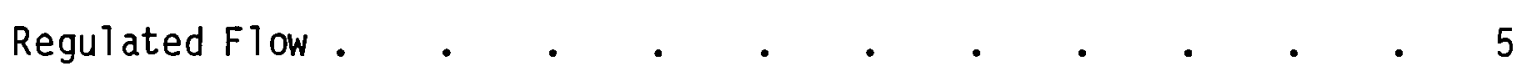

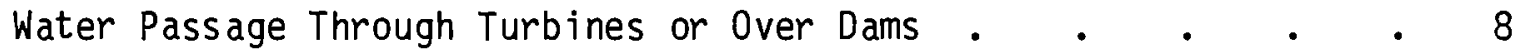

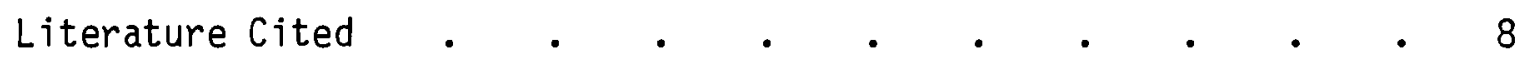

SUMMARY OF PNL RESEARCH

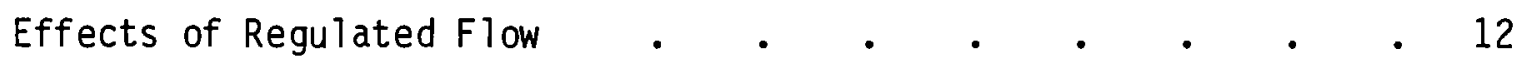

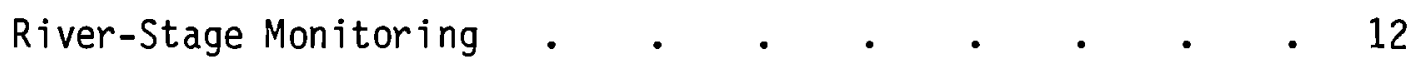

Salmon Redd Surveys .

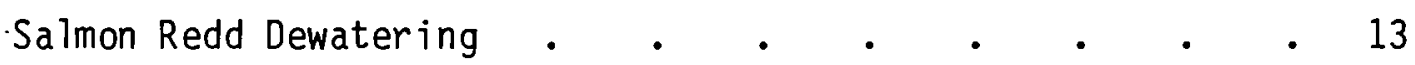

Stranding and Entrapment Surveys . $\quad$ - . . $\quad$ - 13

Centrarchid Nesting Surveys . • • • • • • . 14

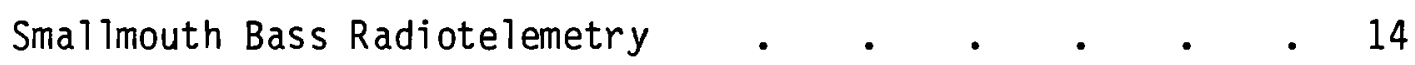

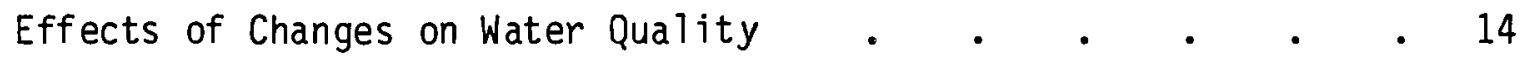

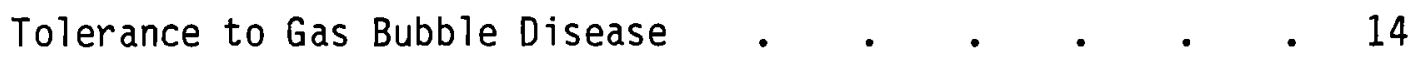

Dissolved Gas Analysis and Monitoring . . . . . . 15

Distribution of Chinook Salmon Relative to Dissolved Gas

Supersaturation $\quad . \quad . \quad . \quad . \quad . \quad . \quad . \quad 15$

Effects of Restricting Fish Movement and Migration $\quad$ - $\quad$ - 15

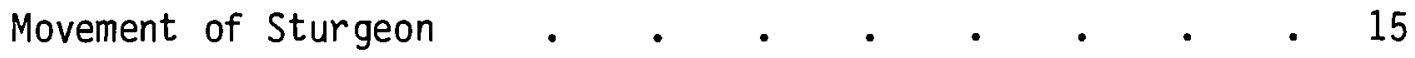

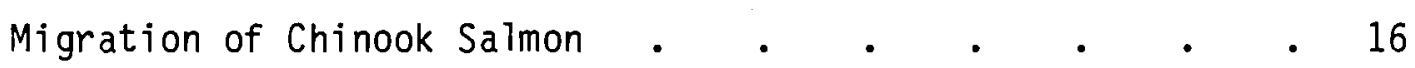

Fish Disease Resulting from Concentration _ . . $\quad$ • $\quad$ - 16

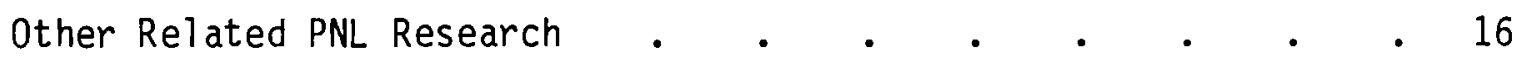




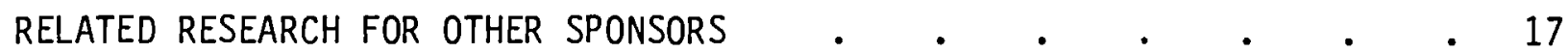

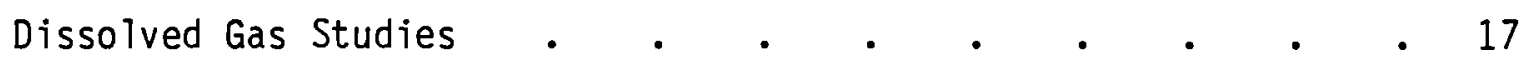

Hydroelectric Impact Assessment . . . . . . . 17

Migration of Juvenile Salmonids . $\quad$ - . . . . 17

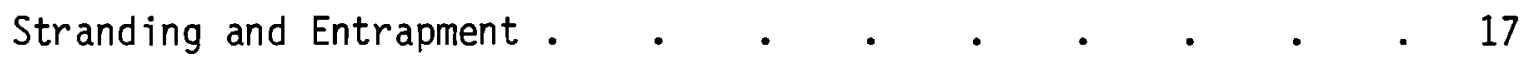

Impingement at Water Intakes . . . . . . . . 18

RESEARCH NEEDS •

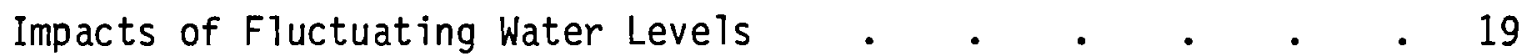

Impacts on Critical Habitats . $\quad . \quad \ldots \quad . \quad$. $\quad$. 20

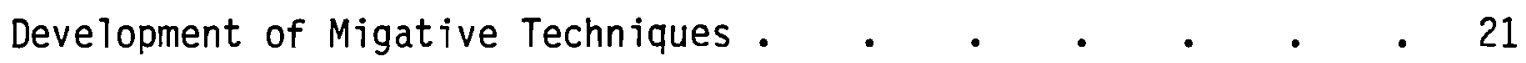

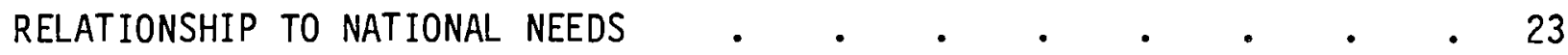

BIBLIOGRAPHY OF PNL RESEARCH • • • • • • • • • • • • 


\section{INTRODUCTION}

Hydroelectric generation occurs throughout the United States at dams and pumped storage facilities. Dams generally are constructed across flowing bodies of water, which allows the flow to be directed through turbine generators. Dams are also constructed and licensed to aid navigation, store water for irrigation, and to control flooding. As the fiscal and environmental cost of fossil- and nuclear-fueled electrical generators increase, and as the public opposition to them grows, it becomes cost effective to modify existing dams built without generators to provide new electrical generation capacity and to construct new low-head facilities on small streams. At pumped storage facilities, two reservoirs located near each other but separated by a difference in elevation provide sufficient head for falling water to drive turbine generators.

The expansion of hydroelectric capacity, however, is not free of environmental problems. Pumped storage, conventional hydroelectric dams, and the addition of turbines at non-hydroelectric dams affect aquatic habitats. We identify some of these effects, discuss recent PNL research related to these effects, and discuss research needs and the application of these research projects to hydroelectric generation. 
Whether electricity is generated by conventional hydroelectric dams, by turbines added to existing dams, or by pumped storage facilities, water has to be stored, water flow has to be regulated, and water has to pass through turbines. Environmental impacts related to these events vary not only with the mode of operation, but also with the physical and environmental characteristics of the facility's location (Table 1). Depending on design and operational characteristics, some dams store water for a whole season while others are restricted to daily storage. Some water withdrawal systems permit selection of depth at which water is withdrawn to control discharge temperature, while others are restricted to a single depth. Turbines differ in design, amount of and rate at which water passes through them, and in provisions made to protect fish populations. Fish passage facilities, when provided, vary with species requirements and facility location. The characteristic most likely restricted by facility location is hydraulic head.

The environment of each hydrogenerating facility must be considered when predicting and assessing impacts. Dams on rivers or streams used by anadromous fish can delay or block migration. When a stream is impounded for a pumped storage facility, ecological change is accelerated and the resident fish populations change in number and composition. Warm-water species may become more prevalent than cold-water species if water temperatures rise. Benthic invertebrate, algal, and macrophate communities will also be affected by the change from a lotic to lentic habitat. Shoreline community productivity is reduced by water level fluctuations.

The following discussion gives examples of several environmental effects related to water storage, flow regulation, and turbine passage observed at hydrogenerating facilities.

\section{Water Storage}

Dams are built to block rivers or streams so water can be stored in reservoirs and released through turbines to produce electricity. Pumped storage facilities also use reservoirs to store water for electrical generation. 
TABLE 1. Environmental Impacts Related to Water Storage, Regulated Flow, and Passage of Water Through Turbines or over Dams at Hydroelectric Generating Facilities

TYPE OF HYDROELECTRIC GENERATING FACILITY

\begin{tabular}{|c|c|c|c|}
\hline \multirow[b]{2}{*}{ 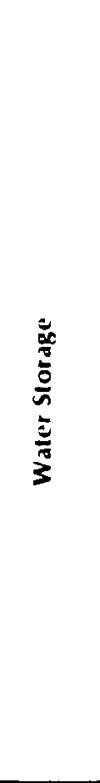 } & Pumped Storage & Conventional Hydroeleciric Dam & "Turbine Addition \\
\hline & $\begin{array}{l}\text { Creates a Reservoir } \\
\text { Inundate drv land or imall } \\
\text { uream } \\
\text { Create new littoral environment } \\
\text { Create new riparian community } \\
\text { Change food base for indige- } \\
\text { nous acjuatic communities } \\
\text { Restructurephysical environment } \\
\text { Restricts Fish Movement and } \\
\text { Migration } \\
\text { Fish pumped to storage reservoir } \\
\text { Disrupts normal current } \\
\text { patterns } \\
\text { Pounible phisical blockage } \\
\text { Changes Water Quality } \\
\text { Storage reservoir may ther- } \\
\text { mally stratify } \\
\text { Alter reservoir temperature } \\
\text { regime } \\
\text { Alter nutrent cycling } \\
\text { Increase turbidits } \\
\text { Increase insolation to aquatic } \\
\text { community } \\
\text { Aerate water low in dissolved } \\
\text { oxygen }\end{array}$ & $\begin{array}{l}\text { Changes Major Stream to } \\
\text { Reservoir } \\
\text { Inundate land and indigenous } \\
\text { riparian community } \\
\text { Change from lotic to littoral } \\
\text { environment } \\
\text { Create new wetlands } \\
\text { Restructurephysical environment } \\
\text { Reduces sediment transport } \\
\text { cdpacity } \\
\text { Restricts Fish Movement and } \\
\text { Migration } \\
\text { Block or delav fish migration } \\
\text { Increase exposure to disease } \\
\text { organisms al fish ladders } \\
\text { Increase predation on popula- } \\
\text { tionudealted or concen- } \\
\text { trated } \\
\text { Changes Water Quality } \\
\text { Reservoir stratified } \\
\text { Alter downstream remperature } \\
\text { regime } \\
\text { Alter healing and cooling of } \\
\text { water }\end{array}$ & $\begin{array}{l}\text { No Change from Dam Without } \\
\text { Turbines }\end{array}$ \\
\hline 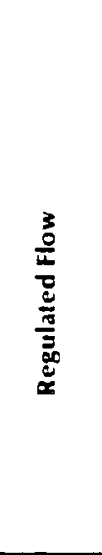 & $\begin{array}{l}\text { Causes Fluctuating Water Levels } \\
\text { Exclude some aquatic organisms } \\
\text { from shoreline areas } \\
\text { Dewater shoreline spawning } \\
\text { and rearing areas for fish } \\
\text { Cyclically flood and dewater } \\
\text { riparian communities } \\
\text { Sirand and entrap fish } \\
\text { Affect carbon flux by altering } \\
\text { primary production } \\
\text { Increase bank crosion } \\
\text { Changes Water Quality } \\
\text { Water in shoreline areas cub- } \\
\text { ject to wide changes in water } \\
\text { temperature and dimelved } \\
\text { oxvgen concentrations dur- } \\
\text { ing periodsof fluctuation } \\
\text { Change in turbidity }\end{array}$ & 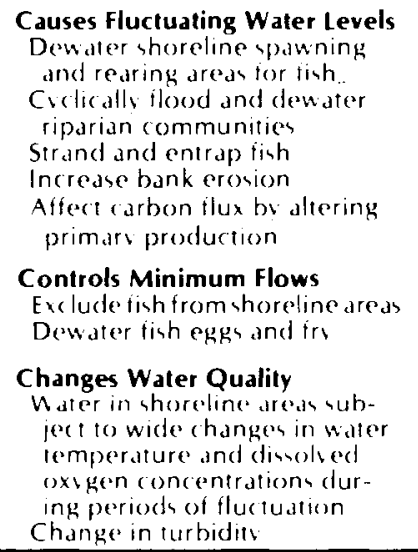 & $\begin{array}{l}\text { Causes Fluctuating Water Levels } \\
\text { Crclically flood and dewater } \\
\text { riparian communities } \\
\text { Strand and entrap fish } \\
\text { Increase bank erosion } \\
\text { Controls Minimum Flows } \\
\text { Exclude fish from shoreline areas } \\
\text { Dewater fish eggs and fry }\end{array}$ \\
\hline 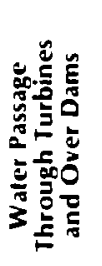 & $\begin{array}{l}\text { Causes Entrainment } \\
\text { Organisms Pass through } \\
\text { potentially lethal pressure } \\
\text { iransients } \\
\text { Mechanic al injury to organisms } \\
\text { Changes Water Quality } \\
\text { Gas supersaturation } \\
\text { Recyele nutrients in heredine } \\
\text { cone }\end{array}$ & 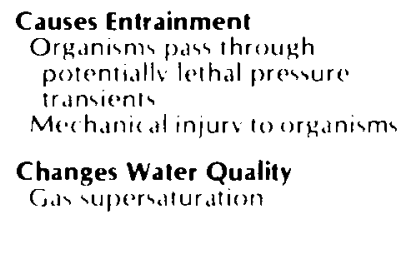 & $\begin{array}{l}\text { Causes Entrainment } \\
\text { Organisms pass through } \\
\text { porentially lethal pressure } \\
\text { transients } \\
\text { Merhanical injury to organism } \\
\text { Changes Water Quality } \\
\text { Cas rupersaturation }\end{array}$ \\
\hline
\end{tabular}

- Impact listed are these identified for the addition of turbines to existing non-generating dams. 
These reservoirs inundate large areas of land, change current patterns, flood existing riparian communities, and create new shoreline areas (Table 1). Baxter and Glaude (1980) review environmental effects of dams and impoundments in Canada.

Inundation caused by an impoundment provides new aquatic habitats. Fish that require flowing water for spawning may no longer be able to reproduce and are replaced by species adapted to reservoir habitats. When fish passage is blocked by a dam, anadromous and catadromous species may be excluded from. spawning areas. This eventually results in fish loss or displacement of whole fish populations. Habitat changes resulting from impoundment may affect other aquatic organisms, particularly benthic invertebrates.

In British Columbia, Canada, pre- and post-impoundment studies were conducted on the Campbell river system (Geen 1974). Major changes were observed in benthic populations from Buttle and Lower Campbell lakes after impoundment. In Buttle Lake, organism abundance decreased after impoundment, and some benthic species completely disappeared. Andrusak (1972) studied the distribution of rainbow trout (see Table 2 for a list of common and scientific names for fish species discussed in this report) in Kootenay Lake, British Columbia, after the filling of Duncan Dam reservoir. As the result of changed current patterns and altered temperature-turbidity-discharge regimes, rainbow trout were redistributed within the lake.

Fickeisen (1979) discusses environmental impacts related to the development of pumped storage reservoirs. Larger-sized fish species are expected, and warm-water species may become more prevalent than cold-water species in pumped storage reservoirs. Carp, suckers, and largemouth bass may replace trout and smallmouth bass at many locations. Sculpins may be replaced by sunfish and perch, and the benthic insects such as stoneflies and caddisflies that require flowing water may be replaced by reservior forms such as chironomids and mayflies.

Regulated Flow

Water flows at hydroelectric generating facilities are regulated. Water can be stored to reservoir capacity and held for use during periods of peak 
TABLE 2. Common and Scientific Names of Fish Used in this Report

Common Name

black bullhead
bluegill
bridgelip sucker
chinook salmon
cisco
common carp
smallmouth bass
largemouth bass
largescale sucker
northern squawfish
northern pike
pumpkinseed
rainbow steelhead trout
lake trout
shad
white sturgeon
walleye
yellow perch

Scient if ic Name

Ictalurus melas (Raf.)

L. macrochirus Raf.

Catostomus columbianus

(Eigenmann and Eigenmann)

O. tshawytscha (Wa lbaum)

Coregonus spp.

Cyprinus carpio L.

Micropterus dolomieui Lacepède

M. salmoides (Lacepède)

C. macrocheilus Girard

$\frac{\text { Ptychocheilus }}{\text { (Richardson) }}$ oregonens is

Esox lucius L.

Lepomis gibbosus (L)

Salmo gairdneri (Richardson)

Salvelinus namaycush (Walbaum)

Alosa spp.

Acipenser transmontanus (Richardson)

Stizostedion vitreum (Mitchi11)

Perca flavescens (Mitchill)

power demand. Additionally, dams often regulate flow to aid navigation, store water for irrigation, or provide flood control. Regulating flows cause fluctuating water levels and can change water quality (e.g., temperature, atmospheric gas concentration, and turbidity) up and downstream from the hydrogenerating facility. Bennett Dam on the Peace River in Alberta, Canada, regulates the river discharge (Anon. 1971), resulting in the disruption of flows to downstream wetland areas. Spawning areas for cisco along the shores of Lake Athabasca are adversely affected. Cisco are the basic food supply for the 
important harvestable fish populations in the area such as walleye, pike, and lake trout. With a major decline in the cisco food base, these commercial fish are threatened.

Controlled flows at Priest Rapids Dam in Washington have been used during fall months to prevent chinook salmon spawning in shoreline areas that are regularly dewatered during the winter by peaking power production at the dam (Bauersfeld 1978). These flow regulations were initiated to mitigate adverse effects of water level fluctuations that occur during chinook salmon spawning, egg incubation, and fry development (Bauersfeld 1978).

In the Pacific Northwest, loss of juvenile salmonds and other fish by stranding as a result of acutely fluctuating river flows has become a major concern of fishery resource managers (Bayha and Koski 1974; Thompson 1970). Haber, Moore and Hicks (1978) review present and potential impacts of fluctuating flows on the lower Clearwater River, Idaho, and provide references to relevant on-site studies. Becker et al. (1981) present some effects of waterlevel fluctuations on fish in the Hanford Reach of the Columbia River.

Regulated water levels have also been used as a fishery management tool to control undesired fish populations (carp, shad, squawfish) in reservoirs by excluding these fish from spawning habitats and exposing previously spawned eggs.

Fluctuating water levels in pumped storage reservoirs and currents that occur during the pumping or generating mode of operation may prevent development of seasonal thermal stratification or alter water quality by changing the distribution of industrial discharges (Reynolds 1977). Altered current patterns may also disrupt normal migration and movement of fish.

Hildebrand et al. (1980) report several environmental impacts related to water level fluctuations resulting from the development and operation of smallscale hydroelectric dams. The major impacts include resuspension and redistribution of bed and bank sediment; leaching of soluble matter from the littoral zone and the shoreline; changes in sediment, nutrient retention, and water quality; loss of available habitat; reduced productivity; and shifts in species diversity. 
Water Passage Through Turbines or Over Dams

Hydroelectric generating facilities pass water through turbines to produce power. Aquatic organisms entrained by water passing through turbines are subjected to mechanical injury and to potentially lethal pressure transients.

Passage through turbines is a major problem affecting juvenile salmonid survival in the Columbia River (Schoeneman, Pressey and Junge 1961; 01 son and Kaczynski 1980). Snyder (1975) reports large numbers of fish are pumped from the lower reservoir to the storage reservoir at the Muddy Run pumped storage facility in Susquehanna, Pennsylvania. Fickeisen (1979) discusses the effect of turbine entrainment at pumped storage facilities and the difficulties in quant ifying losses in such large-volume systems.

As water passes through turbines or over dams, atmospheric gas can be entrained and supersaturate the water with dissolved gases. Supersaturation may be potentially lethal to aquatic organisms near hydroelectric facilities.

The effects of gas supersaturation have been reviewed by weitkamp and Katz (1980). The impacts of turbine passage and exposure to increased gas saturation must be included in the assessment of impacts from hydroelectric generation.

In a thermally stratified system, the level at which water is withdrawn and released through turbines influences the temperature of the discharged water and the thermal profile of the impoundment. Some high-head dams have provision to control the level of withdrawal in order to control water temperature downstream. The level can be seasonally adjusted to provide for management of river temperatures.

\section{Literature Cited}

Andrusak, H. 1972. Kootenay Lake Sport Fishery 1970-71. B.C. Fish Wildl. Branch (cited in Geen 1974).

Anon. 1971. Fisheries Problems Related to Moran Dam on the Fraser River. Dep. Environ. Fish. Serv., Int. Pac. Salmon Fish. Comm. (cited in Geen 1974).

Bauersfeld, K. 1978. The Effect of Daily Flow Fluctuations on Spawning Fall Chinook in the Columbia River. Tech. Rep. No. 38, wash. Dept. Fish, OTympia, Washington. 
Baxter, R. M., and P. Glaude. 1980. Environmental Effects of Dams and Impoundments in Canada, Experience and Prospects. Department of Fisheries and Oceans, Ottawa, Canada.

Bayha, K., and C. Koski. 1974. Salmonids, Chap. 7. In: Anatomy of a River. Pacific Northwest River Basins Commission, Vancouver, Washington.

Becker, C. D., D. H. Fickeisen and J. C. Montgomery. 1981. Assessment of Impacts from Water Level Fluctuations on Fish in the Hanford Reach of the Columbia River. PNL-3816, Pacific Northwest Laboratory, Richland, Washington (in press).

Fickeisen, D. H. 1979. Pumped Storage Environmental Effects: Assessment of Research Needs. PNL-2671, Pacific Northwest Laboratory, Richland, Washington.

Geen, G. H. 1974. Effects of hydroelectric development in western Canada on aquatic ecosystems. J. Fish. Res. Board Can. 31:913-927.

Haber, D. F., B. Moore and W. Hicks. 1978. A Review of the Impacts of Fluctuating Flows on the Lower Clearwater River and Recommendations for Future Studies. Idaho Water Resources Research Institute, University of Idaho, Moscow, Idaho.

Hildebrand, S. G., R. R. Turner, B. Tschantz, L. D. Wright, S. Tam and A. T. Szluha. 1980. Analys is of Environmental Issues Related to Small-Scale Hydroelectric Development. III: Water Level Fluctuation. TM-7453, Oak Ridge National Laboratory, Oak Ridge, Tennessee.

01son, F. W., and V. W. Kaczynski. 1980. Survival of Downstream Migrant Coho Salmon and Steelhead Trout Through Bulb Turbines. Prepared for public Utility District No. 1 of Chelan County by CH2M Hill Inc., Bellevue, Washington.

Reynolds, J. Z. 1977. Water quality in pumped storage reservoirs. J. Power Div., Am. Soc. Civil Eng. 93:15-35.

Schoeneman, D. E., R. Pressey and C. 0. Junge, Jr. 1961. Mortality of downstream migrant salmon at McNary Dam. Trans. Amer. Fish. Soc. $90(1): 58-72$.

Snyder, D. E. 1975. Passage of fish eggs and young through a pumped storage generating station. J. Fish Res. Bd. Canada 32: 1259-1266.

Thompson, J. S. 1970. The Effect of Water Flow Regulation at Gorge Dam on Standing of Salmon Fry in the Skagit River. Research Report, Washington Department of Fisheries, 01ympia, Washington.

Weitkamp, D. E., and M. Katz. 1980. A review of dissolved gas supersaturation 1iterature. Trans. Amer. Fish. Soc. 109:659-702. 


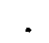


SUMMARY OF PNL RESEARCH

For over a decade, the Ecological Sciences Department of Pacific Northwest Laboratory has examined effects of hydroelectric generating facilities on aquatic ecosystems. Most of our work has been related to effects of: 1) regulated flow, 2) changes in dissolved gas levels, and 3) restrictions on fish movement and migration. We emphasized development of methods and application of site-specific findings to achieve a generic understanding of the major aquatic impacts arising from hydroelectric generation. Publications describing past and current studies conducted in our laboratories in the adjacent reach of the Columbia River and at off-site locations are listed in the bibliography accompanying this report.

Communicating program results to federal and state water resource managers, to hydroelectric generating agencies, to the public, and to the scientific community is one of the priorities of project management. We also coordinate our research with other research and regulatory groups at various governmental levels.

In addition to presentations and formal publications on project research, our personnel participate in related professional activities. Scientists at PNL have served as members of the Interagency Nitrogen Task Force to coordinate research on gas bubble disease and to provide a route of communication among involved agencies; we hosted a Gas Bubble Disease Workshop in 1974, published proceedings of this workshop, and recently edited a special section on gas bubble disease in Transactions of the American Fisheries Society. We summarized the results of columnaris disease research at PNL from 1965 through 1973, focusing on epizootiology in the Columbia River system, and published the data as a monograph in 1978. We presently serve on an informal coordinating committee to design research projects on predator-prey interactions in the Columbia River system as they relate to effects of hydroelectric impoundments, fishways, and spillway effects. C. D. Becker served as Associate Editor of Transactions of the American Fisheries Society. We have published a large number of journal articles and technical reports discussing the impacts of hydrogenerating facilities on the aquatic environment. 
A summary of PNL research related to hydroelectric generation that was funded by the Department of Energy and its predecessors follows. For additional details, refer to PNL Annual Reports and to articles and reports in the bibliography at the end of this report.

\section{Effects of Regulated Flow}

Changes in flow regimes caused by peaking power generation impose severe daily river-stage fluctuations in the Hanford Reach of the Columbia River. Such large and sudden changes create an unstable shorezone and affect water temperatures. Potential impacts include alternately flooding and dewatering wide beach areas, which affect shallow-water periphyton, macrophytes, benthos, and fish dependent on shoreline habitat. Our studies have focused on the effects of these fluctuations on fish populations that use shallow-water, shoreline habitats for spawning, rearing, and nursery areas.

\section{River-Stage Monitoring}

We developed a pressure-sensitive radiotelemetry system that permits continuous remote recording of river stage. Three telemetry system devices were used to monitor changes in river stage in study areas concurrent with stranding, entrapment, and smallmouth bass nesting studies. River stage varies by as much as $2 \mathrm{~m}$ on a typical day in response to the cumulative effects of peaking power operation at upstream dams. River-stage data are supplemented by topographical surveys, beach slope and exposure data, and by water temperature records. Together, these data provide the basis for a future modeling effort to describe changes in river stage as a result of changes in flow release from upstream dams. Additionaliy, this modeling effort will relate river-stage changes to environmental impacts.

\section{Salmon Redd Surveys}

PNL has conducted annual surveys of fall chinook salmon redds in the Hanford Reach since 1947. These aerial counts of redds provide a relative index of fall chinook salmon spawning activity. The surveys indicate a trend toward increased numbers of chinook spawners during most of this recorded period, but spawning numbers have stabilized in recent years. The most remarkable feature of the data is several sudden increases in the number of salmon 
redds observed, which occurred simultaneously with filling of impoundments on upstream parts of the river. This increased spawning apparently represents displacement of fall chinook salmon from historic spawning sites where the free-flowing river was transformed into reservoirs.

\section{Salmon Redd Dewatering}

Storage and manipulation of water levels result in potential dewatering of areas where fish species that construct nests or have demersal eggs normally spawn. Such dewatering may result in exposure of developing eggs. We studied the effects of dewatering on developing chinook salmon eggs and fry in artificial redds. Four intergravel developmental stages were tested. The developmental stage most tolerant to dewatering was the stage from "eyed-egg" to hatching. Eggs from fertilization to the eyed-egg stage and fry are less tolerant of dewatering. Egg-sac fry were killed by brief dewaterings. They need protection against exposure to such conditions. These results, when fully analyzed, will be of use to water resource managers in providing the maximal protection for developing eggs and fry during critical periods in areas with limited water supplies.

\section{Stranding and Entrapment Surveys}

As a result of changes in river stage, shorezone organisms are subject to stranding above the water line or entrapment in pools that form as river level recedes. We conducted observational surveys of these phenomena and found that stranding is relatively unimportant where the beach slope is steep and the change in river stage is slow. However, fish, invertebrates, and insects are subject to entrapment in ponds. Large numbers of small fish that use shorezone areas for nursery grounds become entrapped and subsequently lost due to 1) predation by terrestrial mammals or birds, 2) temperature rises in excess of thermal tolerance limits, or 3) dewatering of the ponds. Dewatering effects are strongly dependent on substrate and bank storage of water. Water remaining in the shorezone substrate may slow the rate of dewatering. We are designing experiments to quantify these losses and relate them to the rate of change and duration of reduced river stage. 


\section{Centrarchid Nesting Surveys}

We have examined the effects of fluctuating water levels on reproduction success of the smallmouth bass. Dewatering of nesting areas and changes in water temperature caused by fluctuating water levels have strong potential for disrupting spawning. Nest surveys indicate an unusually high proportion of newly constructed nests. Sudden temperature changes may cause suppression of spawning, disruption of embryogenesis, or changes in the guarding behavior of adult males, thereby allowing other fish to prey on the eggs.

Smallmouth Bass Radiotelemetry

Movements of smallmouth bass were monitored with externally-mounted radiotransmitters during and immediately following spawning. Tagged adults tended to stay on the spawning ground throughout the nesting season and then moved from the backwater areas used for nesting to deeper mainstem river areas. A significant difference in distance traveled after the spawning season was observed for fish using two different spawning areas. Results were corroborated by dart tags returned by sport fishermen.

Effects of Changes on Water Quality

A major effect of hydroelectric generation on water quality is generation of water supersaturated with dissolved atmospheric gas. Several of our research tasks over the past decade involved defining the degree and extent of gas supersaturation and the tolerance of aquatic biota to gas bubble disease, which results from exposure to gas supersaturated water. The Columbia River, for example, has been severely affected in past years when excess water was passed over dam spillways; the water became supersaturated and fish were exposed to lethal conditions.

Tolerance to Gas Bubble Disease

An extensive series of bioassays was conducted to determine tolerance of three fish species to gas bubble disease at different temperatures. The results indicated important species differences. Tolerance decreased with increased temperature for a given species. These studies with rainbow trout, black bullhead, and pumpkinseed sunfish were conducted in shallow tanks that 
did not have sufficient depth to permit a significant degree of hydrostatic pressure to compensate for the excess of dissolved atmospheric gases.

Dissolved Gas Analys is and Monitoring

We tested and refined several methods to determine the supersaturating levels of oxygen and nitrogen dissolved in water. These included both field and laboratory methods for total gas and for the principal component gases. We surveyed dissolved gas levels in the Columbia and Snake rivers as well as in tributary streams to develop an understanding of the mechanisms of supersaturation and define typical dissolved gas regimes in streams with and with- : out hydroelectric generation facilities.

Distribution of Chinook Salmon Relative to Dissolved Gas Supersaturation

Radiotelemetry was used to monitor the depth distribution and movements of chinook salmon in the Snake River relative to dissolved gas levels. Compensation for supersaturation is available in deeper waters from increased hydrostatic pressure, which reduces the level of supersaturation for a given gas content in water. Thus, if $f$ ish responded to supersaturation by sounding, they could reduce the danger of exposure to gas bubble disease. Our studies were the basis of a doctoral dissertation demonstrating that adult chinook salmon returning upriver during a period of potentially dangerous supersaturation swam deeper than chinook migrating during a period of near-normal saturation. During the period of supersaturation, the fish spent most of their time below the critical zone where gas bubble disease could occur. Effects of Restricting Fish Movement and Migration

Large dams effectively block or delay the migration and movement of fish. Often fish passage facilities are constructed to mitigate these effects, but these are often the source of a new set of impacts. We examined movements of resident and anadromous species under different flow regimes as well as the role of fish ladders in concentrating fish and the spread of infectious diseases.

Movement of Sturgeon

Columbia River sturgeon at one time made extensive round-trip migrations from upriver areas to the estuary. However, construction of many hydroelectric 
dams on the river system blocked that movement. We used external radiotransmitters to monitor movements of adult and sub-adult sturgeon in the Hanford Reach of the Columbia River. Movements seemed keyed to water temperature; during periods of cool temperature, they tended to remain in deep pools, but movements began when temperatures warmed in the spring. The direction of travel was somewhat dependent on the size of the fish monitored.

\section{Migration of Chinook Salmon}

For 2 years, radio-tagged adult chinook salmon were tracked to evaluate their delays at dams and swimming depth distribution as they moved between and over Snake River dams. Although the fish traveled quickly between dams (in 1 to 3 days), they spent up to 5 weeks passing over the fishways. Some fish were never recorded as having crossed the dams.

\section{Fish Disease Resulting from Concentration}

We studied the incidence of columnaris disease caused by Flexibacter columnaris in anadromous salmonids. Infected resident fish that release disease organisms are frequently found in fish ladders and at other sites related to dams. Areas such as fish ladders concentrate fish and increase chances of infection. It is probable that such sites are important in the spread of other communicable fish diseases.

Other Related PNL Research

We conducted a review of the environmental effects of pumped storage hydrogeneration and identified research needs related to pumped storage. In 1975, we made a preliminary assessment of the effects that discharge from the $\mathrm{N}$-Reactor in the Hanford Reach of the Columbia River had on water temperature and aquatic ecology. At the request of the Richland Operations office, we reviewed potential effects that construction of the Ben Franklin Dam in the Hanford Reach of the Columbia River would have on Hanford Operations. These assessmemts would not have been possible, or would have lacked considerable accuracy, without the background and experience that PNL personnel have obtained over the years from working on programs supported by the Department of Energy and its predecessors. 


\section{RELATED RESEARCH FOR OTHER SPONSORS}

In addition to operating the Pacific Northwest Laboratory for the Department of Energy, Battelle Memoral Institute contracts with other government and private sponsors for research work. Some of this research has been related to hydrogeneration and is summarized here.

\section{Dissolved Gas Studies}

We conducted dissolved gas surveys in the lower Snake River for the North Pacific Division, U.S. Army Corps of Engineers for use in calibrating a mathematical model relating spillway/discharge volume to supersaturation. Studies of the effects of hydrostatic pressure compensation on gas bubble disease tolerance and the effects of gas supersaturation on aquatic insect larvae were conducted for the Seattle District, U.S. Army Corps of Engineers.

\section{Hydroe lectric Impact Assessment}

We conducted a comprehensive assessment of the Ben Franklin Dam alternative for future development of the Hanford Reach of the Columbia River. Sponsored by the Seattle District U.S. Army Corps of Engineers, these studies examined effects on 1) fish and aquatic resources, 2) wildlife usage of riparian areas, 3) riparian plant communities, and 4) rare and endangered species that could be affected. The study included extensive mapping of habitats and analysis of mitigation measures that could be employed.

Migration of Juvenile Salmonids

We are assisting Public Utility Districts in the mid-Columbia area by advising them on sampling design of experiments to determine effects of controlled spillway operation on the downstream movement of marked juvenile salmonids.

\section{Stranding and Entrapment}

To facilitate design and construction of river water intakes for the Washington Public Power Supply System (WPPSS) nuclear projects, river flow was decreased to its minimum permitted level $(36,000 \mathrm{cfs})$ at Priest Rapids. Under contract to United Engineers and Constructors, we surveyed stranding and entrapment of fish during this brief study when Hanford Reach river stage was rapidly 
dropped to the lowest licensed flow allowable and held there for several hours. Adult course fish were stranded in some areas where beach slope was gradual, and adults and juveniles of several species were entrapped in small ponds and backwater areas.

Impingement at Water Intakes

We have conducted studies of impingement of fish on the WPPSS Hanford Generating Plant intake screens. An inverse correlation was found between river stage and impingement velocity. At low water levels the velocity of water approaching and passing through the traveling screens is higher than it is at higher water levels.

We appraised the effects of various water intake systems on the central Columbia River in relation to nuclear power plants planned by WPPSS in 1973. 


\section{RESEARCH NEEDS}

Our evaluation of PNL's research to date suggest the following research is needed to more comprehensively understand the impacts of hydroelectric development on aquatic biological systems.

Impacts of Fluctuating Water Levels

Short-term (daily) changes in river flow and the resultant water level fluctuations need to be correlated with biological impacts. Using hydrogeneration to meet peaking power needs significantly changes turbine loading and, therefore, river stage. Pumped storage projects experience even more severe changes in reservoir water levels during operation than do conventional hydro projects. Such changes affect the littoral zone and its associated communities. Research is needed to determine the severity of impacts and quantitatively predict the effects of proposed operating schemes on aquatic resources.

We have an extensive data base on river stage and temperature for study areas where we simultaneously collected biological data. Limnological surveys support the data base. Biological data include observations of stranding and entrapment of shore-zone fish, nesting surveys for smallmouth bass, and studies of the effects of repeated dewatering of artificial redds on the survival and development of salmon eggs and larvae.

Correlation techniques are needed to relate river stage and water temperature changes and to extend that information to quantifying biological impacts. Existing models relate flow to stage, but these have not been specifically designed for the shallow shore zone, particularly backwater areas that are biologically important, and they do not predict temperature changes that result from changes in stage. Such model refinement is possible with our existing information. Although the model would be developed largely with site-specific data, generic application can be made by field data from other locations.

Additional information needed to evaluate effects on biota include: 1) quantification of stranding and entrapment as they relate to beach slope, topography, and substrate; 2) evaluation of effects of fluctuating water levels 
on primary and secondary productivity; 3) definition of effects of fluctuating temperature regimes on fish embryogenesis; and 4) behavioral observations of mobile aquatic populations. Additional physical data need to be developed relating water temperature to meteorological conditions and changes in river stage. Improving and expanding our monitoring capabilities to record water quality would help refine the model. To predict effects on fish spawning areas, information is needed on bank storage of water, rate at which typical spawning substrate dries, and temperature changes in spawning areas exposed to the air.

Impacts on Critical Habitats

Hydroelectric generation causes major physical changes in the environment due to impoundment, inundation, and controlling the release of water. The effect of habitat changes on aquatic populations needs to be evaluated. Although we can predict the effects a given project will have on the habitat, critical habitats and their use by some aquatic organisms have not been clearly defined. A list of generic criteria for defining critical habitats must be developed. Specific data adapted to the criteria then must be assembled from the literature, field work, or both. After critical habitats are defined, we can assess how they are affected by a proposed project.

Our past work has provided some regional information relevant to this task, including a historical data base on salmon redd counts, data on reproduction of smallmouth bass, and movements of sturgeon, smallmouth bass, and adult chinook salmon.

Life history data for important but little understood species such as sturgeon are needed to evaluate and identify critical habitats and related information that describes the ecosystem structure and function. Critical habitat requirements and the degree of their flexibility need to be identified. For example, we need to know which species are dependent on flowing water for spawning and which ones require stable shore zones. The regional importance of the populations affected partially determines the severity of a particular impact. 
Development of Mitigative Techniques

As we become increasingly aware of competition for the use of limited resources and of the consequences of unbalanced resource management, we realize the importance of mitigating adverse impacts and creatively managing our resources to optimize their value. Data from field and laboratory studies that can be used to optimally allocate water resources while protecting the aquatic ecological community need to be collected and made available to resource managers.

We already have preliminary data on the relative dewatering tolerances of chinook salmon eggs and fry, surveys of smallmouth bass nesting, and habitat conditions expected to occur after the construction of hydrogeneration plants.

Future research is needed to identify and evaluate ways to alleviate adverse impacts from hydrogeneration. Proposed techniques include the use of sprinklers to irrigate spawning areas that are dewatered; the use of diking to limit fluctuations of water level and temperature in backwater areas; and the use of controlled-flow regimes during critical biotic periods to limit adverse physical effects. In addition, changes in habitat resulting from hydrogeneration offer opportunities to enhance riparian and wetland communities, and these opportunities need to be identified and evaluated. 


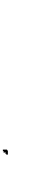




\section{RELATIONSHIP TO NATIONAL NEEDS}

As we seek independence from foreign petroleum supplies and attempt to develop our nation's renewable energy resources, the generation of hydroelectric power will be an increasingly important consideration. Development will involve conventional and pumped storage systems; retrofitting of existing non-generating dams with generators; creating new hydrogeneration capacity at small dams (low-head dams on small tributaries with less than $50 \mathrm{MW}$ generation capacity); and changes in operating modes at existing dams to optimize power generation. At the same time, competing uses for water resources (irrigation, navigation, fish production, thermal power generation, etc.) have focused attention on water scarcity and on the need to manage rivers and reservoirs as integrated systems.

Analysis of environmental impacts is required by state and federal legislation prior to development of new hydrogeneration facilities. As a part of the licensing and permitting process, utilities are required to evaluate adverse effects of their proposed facility and to consider ways to mitigate losses of fish and wildlife. Our research program is designed to provide the background information required for such evaluatons and to facilitate development of hydrogeneration resources while providing a reasonable level of protection for aquatic environments.

If we are to protect aquatic ecosystems for their contribution to world ecosystem functioning, quality of life, and the economic value of the fisheries they support, we need to continually examine the relationship of these living communities to their physical environment and how they are affected by water resource management and development. 


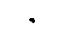

. 


\section{BIBLIOGRAPHY OF PNL RESEARCH}

Becker, C. D. 1980. Columbia River thermal effects study: reactor effluent problems. J. Water Pollut. Cont. Fed. 45:913-925.

Becker, C. D. 1980. Haematozoa from resident and anadromous fishes of the central Columbia River: a survey. Can. J. Zool. 58:356-362.

Becker, C. D., D. H. Fickeisen and J. C. Montgomery. 1981. Assessment of Impacts from Water Level Fluctuations on Fish in the Hanford Reach of the Columbia River. PNL-3816, Pacific Northwest Laboratory, Richland, Washington

Becker, C. D., and M. P. Fujihara. 1978. The bacterial pathogen Flexibacter columnaris and its epizootiology among Columbia River fish. Am. Fish. Soc. Monogr. No. 2.

Coutant, C. C. 1970. Exploratory Studies of the Interactions of Gas Supersaturation and Temperature on Mortality of Juvenile Salmonids. BNWL-1529, Pac ific Northwest Laboratory, Richland, Washington.

Coutant, C. C., and R. G. Genoway. 1968. An Exploratory Study of Interaction of Increased Temperature and Nitrogen Supersaturation on Mortality of Adu $1 t$ Salmonids. Prepared for the U.S. Bureau of Commercial Fisheries by Battelle, Pacific Northwest Laboratories, Richland, Washington.

Fickeisen, D. H. 1974. Final Study Plan: Libby Dam Dissolved Gas. Prepared for the U.S. Army Corps of Engineers, Seattle, by Battelle, Pacif ic Northwest Laboratories, Richland, Washington.

Fickeisen, D. H. 1979. Pumped Storage Environmental Effects: Assessment of Research Needs. PNL-2671, Pacific Northwest Laboratory, Rich1and, Washington.

Fickeisen, D. H., D. D. Dauble, D. A. Neitze1, W. H. Rickard, R. L. Skaggs and J. L. Warren. 1980. Aquatic and Riparian Resource Study of the Hanford Reach, Columbia River, Washington. Prepared for the U.S. Army Corps of Engineers, Seattle District, by Battelle, Pacific Northwest Laboratories, Rich land, Washington.

Fickeisen, D. H., R. E. Fitzner, R. H. Sauer and J. L. Warren. 1980. Wildlife Usage, Threatened and Endangered Species and Habitat Studies of the Hanford Reach, Columbia River, Washington. Prepared for the U.S. Army Corps of Engineers, Seattle District by Battelle, Pacific Northwest Laboratories, Richland, Washington.

Fickeisen, D. H., and J. C. Montgomery. 1975. Dissolved Gas Supersaturation: Bioassays of Kootenai River Organisms. Prepared for the U.S. Army Corps of Engineers, Seattle, by Battelle, Pacific Northwest Laboratories, Richland, Washington. 
Fickeisen, D. H., and J. C. Montgomery. 1978. Tolerances of fishes to dissolved gas supersaturation in deep tank bioassays. Trans. Am. Fish. Soc. $107(2): 376-381$.

Fickeisen, D. H., and J. C. Montgomery. 1979. Observations of Impacts on Peaking Operations on Smallmouth Bass. Presented to the Annual Meeting of Pacific Fishery Biologists, April 4-6, 1979, Warm Springs, Oregon.

Fickeisen, D. H., J. C. Montgomery and R. W. Hanf, Jr. 1975. Effect of temperature on tolerance to dissolved gas supersaturation of black bullhead, Ictalurus melas. In: Gas Bubble Disease, Proceedings of a workshop held in Richland, WA October 8-9, 1974, D. H. Fickeisen and M. J. Schneider, eds. CONF-741033, Technical Information Center, Oak Ridge, Tennessee.

Fickeisen, D. H., J. C. Montgomery and M. J. Schneider. 1973. Tolerance of Selected Fish Species to Atmospheric Gas Supersaturation. Presented at American Fisheries Society, September 13-15, 1973, Orlando, Florida.

Fickeisen, D. H., and M. J. Schneider, eds. 1975. Gas Bubble Disease, proceedings of a workshop held in Richland, WA, October 8-9, 1974 . CONF-741033, Technical Information Center, Oak Ridge, Tennessee.

Fickeisen, D. H., M. J. Schneider and J. C. Montgomery. 1975. A comparative evaluation of the Weiss Saturometer. Trans. Amer. Fish. Soc. 104:816-820.

Fickeisen, D. H., M. J. Schneider and G. A. Wedemeyer, eds. 1980. Special section: gas bubble disease. Trans. Am. Fish. Soc. 109:657-771.

Gilbert, R. 0., G. J. Paulik and D. G. Watson. 1971. Statistical Analys is of Factors Influencing Fall Chinook Salmon Redd Counts Near Hanford on the Columbia River: 1974-1969. BNWL-SA-3973, Pacific Northwest Laboratory, Richland, Washington.

Gray, R. H., and D. D. Dauble. 1976. New distribution records and notes on life-history and behavior of the sandroller, Percops is transmontana (Eigenmann and eigenmann). Syesis 9:369-370

Gray, R. H., and D. D. Dauble. 1977. Checklist and relative abundance of fish species from the Hanford Reach of the Columbia River. Northwest Sci. $51(3): 208-215$.

Gray, R. H., and D. D. Dauble. 1979. Biology of the sandroller, Percopsis transmontana, in the central Columbia River. Trans. Am. Fish. Soc. $108: 635-638$.

Gray, R. H., and J. M. Haynes. 1977. Depth distribution of adult chinook salmon (Oncorhynchus tschawytscha) in relation to season and gas-supersaturated water. Trans. Am. Fish. Soc. 106 (6):617-620. 
Gray, R. H., and J. M. Haynes. 1979. Spawning migration of adult chinook salmon (Oncorhynchus tschawytscha) carrying external and internal radio transmitters. J. Fish. Res. Bd. Can. 36:1060-1064.

Gray, R. H., D. A. Neitze1 and T. L. Page. 1979. Water intake structures: engineering solutions to biological problems. The Northern Engineer 10(1): $26-33$.

Gray, R. H., T. L. Page, E. G. Wolf and M. J. Schneider. 1974. A Study of Screen Impingement and Passage of Fish at the Hanford Generating Project Water Intake Structure. Prepared for Washington Public Power Supply System by Battelle, Pacific Northwest Laboratories, Richland, Washington.

Haynes, J. M. 1978. Movement and Habitat Studies of Chinook Salmon and White Sturgeon. PNL-2471, Pacific Northwest Laboratory, Richland, Washington.

Haynes, J. M., and R. H. Gray. 1980. Influence of Little Goose Dam on upstream migration of chinook salmon (Oncorhynchus tshawytscha). Fish. Bu 11. 78(1):185-190.

Haynes, J. M., and R. H. Gray. 1981. Diel and seasonal white sturgeon (Acipenser transmontanus) in relation to Columbia River temperatures. Fish. Bu11. 79(2)

Haynes, J. M., R. H. Gray and J. C. Montgomery. 1978. Seasonal movements of white sturgeon (Acipenser transmontanus) in the Mid-Columbia River. Trans. Am. Fish. Soc. 107(2):275-280.

Montgomery, J. C., and C. D. Becker 1980. Gas bubble disease in smallmouth bass and northern squawfish from the Snake and Columbia Rivers. Trans. Am. Fish. Soc. 109:734-736.

Montgomery, J. C., and D. H. Fickeisen. 1978. Spawning and Movements of Smallmouth Bass (Micropterus dolomieui) in the Mid-Columbia River. PNL-2785, Pacific Northwest Laboratory, Richland, Washington.

Montgomery, J. C., and D. H. Fickeisen. 1979. Tolerance and buoyancy of aquatic insect larvae exposed to gas supersaturated water. Environmental Entomology 8:655-657.

Montgomery, J. C., D. H. Fickeisen and C. D. Becker. 1980. Factors influencing smallmouth bass production in the Hanford Area, Columbia River. Northwest Sci. 54(4):296-305.

Nakatani, R. E., G. B. Pauley and M. P. Fujihara. 1966. Salmon Prespawning Mortality Studies at Rocky Reach Dam and Priest Rapids Dam, Washington, from September to November, 1965. Washington State Dept. of Fish., OTympia, Washington. 
Page, T. L. 1976. Observations on Salmon Stranding in the Columbia River, April 1976. Prepared for Washington Public Power Supply System by Battelle, Pacific Northwest Laboratories, Richland, Washington.

Page, T. L., R. H. Gray and D. A. Neitzel. 1976. Fish Impingement Studies at the Hanford Generating Project (HGP) December 1975 through Apri1 1976. Prepared for Washington Public Power Supply System by Battelle, Pacific Northwest Laboratories, Richland, Washington.

Page, T. L., R. H. Gray and D. A. Neitzel. 1977. Fish Impingement and Screen Passage Studies at the Hanford Generating Project. Presented at the annual meeting of the American Fisheries Society, Vancover, B.C.

Page, T. L., R. H. Gray and E. G. Wolf. 1975. Report on impingement studies conducted at the Hanford Generating Project March and April 1975. Prepared for Washington Public Power Supply System by Battelle, Pacific Northwest Laboratories, Richland, Washington.

Page, T. L., D. A. Neitzel and R. H. Gray. 1977. Impingement Studies at the 100-N Reactor Water Intake. BNWL-2401, Pacific Northwest Laboratory, Richland, Washington.

Page, T. L., D. A. Neitzel and R. H. Gray. 1978. Comparative fish impingement at two adjacent water intakes on the mid-Columbia River. In: Proceedings of the Fourth National Workshop on Entrainment and Impingement, ed. L.D. Jensen. Ecological Analysts Communications, Melvine, New York.

Pauley, G. B., and R. E. Nakatani. 1967. Histopathology of "gas-bubble" disease in salmon fingerlings. J. Fish. Res. Bd. Can. 24:967-971.

Schneider, M. J. 1970. Gas bubble disease of salmonid fishes. In: Columbia River Thermal Effects Study, Vol. 1. Biological Effects Studies, pp.38-40. EPA, AEC, and Nat. Mar. Fish. Serv., Washington, D.C.

Schneider, M. J., D. H. Fickeisen and E. W. Lusty. 1972. Atmospheric Gas Data and Analysis, Lower Monumental, Ice Harbor, McNary Dams. Prepared for the U.S. Army Corps of Engineers by Batte11e, Pac ific Northwest Laboratories, Richland, Washington.

Schreiber, C. C., C. D. Becker, J. J. Fuquay and R. A. Chitwood. 1974. Intake system assessment for central Columbia River. J. Power Division, ASCE 100(P02):139-155.

Watson, D. G. 1970. Fall Chinook Salmon Spawning in the Columbia River near Hanford 1947-1969. BNWL-1515. Pacific Northwest Laboratory, Richland, Wahington.

Watson, D. G. 1973. Estimate of steelhead trout spawning in the Hanford Reach of the Columbia River. Prepared for the U.S. Army Corps of Engineers by Battelle, Pacific Northwest Laboratories, Richland, Washington. 


\section{DISTRIBUTION}

No. of

Copies

\section{OFFSITE}

A. A. Churm

DOE Patent Division

9800 S. Cass Avenue

Argonne, I1 60439

Dr. D. H. Hamilton

EV-34, GTN

U.S. Department of Energy

Washington, DC 20545

Dr. R. A. Lewis

EV-34, GTN

U.S. Department of Energy

Washington, DC 20545

David Grimes

EV-34, GTN

U.S. Department of Energy

Washington, DC 20545

Helen McCammon

EV-34, GTN

U.S. Department of Energy

Washington, DC 20545

27 DOE Technical Information Center

Ross G. Antipa

Washington State Dept. of Fisheries

115 General Admin. B1dg.

Olympia, WA 98504

Doug Arndt

Portland District

U.S. Army Corps of Engineers

319 S.W. Pine

Portland, OR 97204

R. W. Brocksen

Environ. Assessment Department

Electric Power Research Institute

P. 0. Box 10412

Palo Alto, CA 94303
No. of

Copies

M. A. Brusven

Idaho Water Resources Res. Institute University of Idaho

Moscow, ID 83843

Ron Bush

Seattle District

U.S. Army Corps of Engineers

P.0. Box C-3755

Seatt 1e, WA 98124

Ron Campbe 11

Regional Siting Team

Northwest Energy Systems Co.

P. 0. Box 1090

Kirkland, WA 98033

Bob Clubb

Puget Sound Power and Light

Puget Power Building

Bellevue, WA 98009

Dr. C. C. Coutant

Environmental Sciences Division

Oak Ridge National Lab.

P.0. Box X

Oak Ridge, TN 37830

Mike B. Dell

Grant Co. Public Utility District

P.0. Box 878

Ephrata, WA 98823

Greg Drais-PBE

Bonneville Power Admin.

P. 0. Box 3621

Portland, OR 97208

Wesley J. Ebel

National Marine Fisheries Services 2725 Montlake, Blvd.

Seatt le, WA 98112

Tony Eldred

Wash. St. Dept. of Game

3860 Chelan Highway

Wenatchee, WA 98801 
Michael W. Erho Douglas Co. Public Utility District 1151 N. Main St.

E. Wenatchee, WA 98801

Duane H. Fickeisen

Rural Route

Cook, WA 98605

J. Roy Hamilton

Pacific Power \& Light Co.

Public Service Bldg.

Portland, OR 97204

B. D. Leman

Chelan Co. Public Utility District

P.0. Box 1231

Wenatchee, WA 98801

Edward M. Mains

Environmental Resources Branch

North Pacific Division

U.S. Army Corps of Engineers

P.0. Box 2870

Portland, OR 97209

James McColquin

Wash. St. Dept. of Game

658 West First

Kennewick, WA 99336

James E. Mudge

Wash. Public Power Supply System

P. 0. Box 968

Richland, WA 99352

Roy E. Nakatani

Fisheries Research Institute

University of Washington

Seattle, WA 98105

$A l$ an $V$. Nebeker

Corvallis Environmental Research Lab, EPA

Western Fish Toxicology Station

1350 S.E. Goodnight Ave.

Corvallis, OR 97330
Karen Northrup

Seatt Te District

U.S. Army Corps of Engineers

P.0. Box C-3755

Seattle, WA 98124

Pacific Northwest River Basins Commission

Columbia River

P.0. Box 908

Vancouver, WA 98660

John R. Palensky

Bonneville Power Admin.

P. 0. Box 3621

Portland, OR 97208

Donn L. Park

National Marine Fisheries Services

2725 Mont lake, Blvd.

Seatt le, WA 98112

Lloyd Phinney

Wash. St. Dept. of Fisheries

115 General Admin. BIdg.

OTympia, WA 98504

John B. Pyrch-ES

Bonneville Power Admin.

P. 0. Box 3621

Portland, OR 97208

Paul J. Rago

U.S. Fish and Wildlife Service c/o Great Lakes Fisheries Lab. 1451 Green Road, Rm. 105

Ann Arbor, MI 48105

Howard L. Raymond

National Marine Fisheries Services 2725 Mont lake, Blvd.

Seattle, WA 98112 
No. of

Copies

Wende 11 E. Smith

Idaho Power Company

1914 N. Amber

Boise, ID 83706

Quentin J. Stober

Fisheries Research Institute

Univ. of Washington

Seattle, WA 98105

Tom Voge 1

Bonneville Power Admin.

P. 0. Box 3621

Portland, OR 97208

Tom Welsh

Idaho Coop. Fish Res. Unit

College of Forestry

University of Idaho

Moscow, ID 83843

Bill Zook

Wash. St. Dept. of Game

P.0. Box 1237

Ephrata, WA 98823
No. of

Copies

ONSITE

DOE Richland Operations Office

H. E. Ransom

58 Pacific Northwest Laboratory

W. J. Bair

C. D. Becker (20)

D. W. Crass

C. E. Cushing

D. D. Dauble

K. E. Harding (4)

D. C. Klopfer

D. A. Neitzel (14)

C. M. Novich

T. L. Page

T. M. Poston

W. H. Rickard

J. A. Strand

W. L. Templeton

B. E. Vaughan

D. G. Watson

Publishing Coordination (2)

Technical Information (5) 
. 